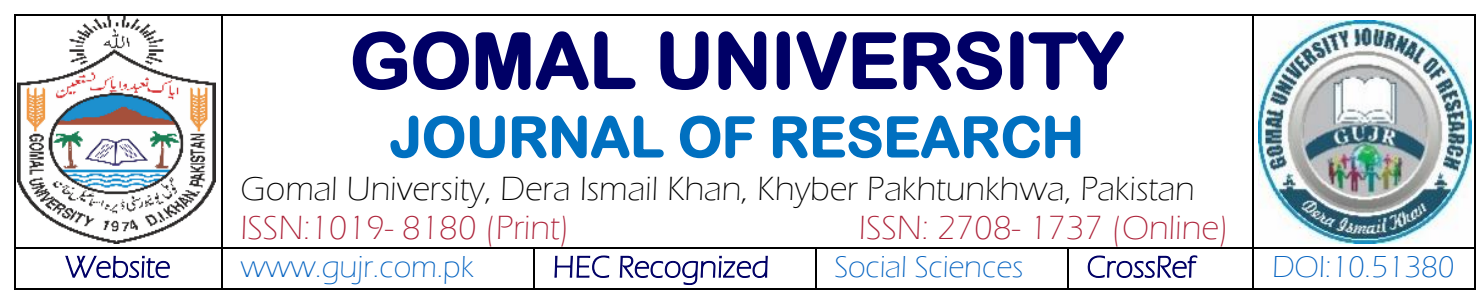

\title{
PUSH AND PULL FACTORS OF NEGATIVE SOCIAL BEHAVIOURS AMONG SECONDARY SCHOOL STUDENTS
}

\author{
Syed Zubair Haider', Uzma Munawar² \& Shaista Noreen ${ }^{3}$ \\ 'Department of Educational Training, Islamia University of Bahawalpur, Pakistan \\ 2Department of Education, Balochistan University of ITE \& MS, (BUITEMS), Pakistan \\ ${ }^{3}$ Department of Education, The Islamia University of Bahawalpur, Pakistan
}

\section{\begin{tabular}{l|l}
\hline KEYWORDS & ABSTRACT
\end{tabular}}

Social Behaviour,

Conflict, Push Factors,

Pull Factors \& Society

\section{Article History}

Date of Submission:

27-12-2020

Date of Acceptance:

18-09-2021

Date of Publication:

30-09-2021
Education is considered critical for both showing positive behaviour and regulating negative social behaviour and affecting the social attitudes by improving one's ability to perceive others. Hence, this research examined the push and pull factors of Negative Social Behaviour among secondary school students. In this research, we collect data over two self-developed questionnaires. Thus, total 500 students (252 female, 248 male) and 120 teachers $(60$ male, 60 female) from 04 districts of Punjab were selected conveniently. The EFA revealed 06 dimensions possibly be extracted from two questionnaires designed for the students and teachers separately. Multilevel analyses mean SD, Pearson correlation, and independent-sample t-test were performed. Findings reveal that parents' conflicts, peer' bullying, teachers' insulting behaviours and students' sarcastic attitude are the major push factors that cause de-motivation and promote NSB among students. These factors severely influence students' personality, and as a result, students lost study interest, behave roughly and violate the institutions' rules.

\section{(c) (1) 8)}

2021 Gomal University Journal of Research

Corresponding Author

Uzma Munawar: druzmamunawar@gmail.com

https://doi.org/10.51380/gujr-37-03-06

\section{INTRODUCTION}

Everyone agrees that education is the perfect way to learn about world around us, how to save it for future generations, and how to build relationship that will ensure our survival (Gazi, 2020). The preschool years are a period of accelerated development of children's cognitive and social skills, which is essential for effective school adaptation (Korucu, Selcuk, \& Harma, 2017). Being socially confident and not purposely harming others are required for healthy social experience (Valiente, Eisenberg, Haugen, Spinrad, Hofer, Liew \& Kupfer, 2011). So, the action is influenced often by thoughts and emotions that disclose information about an individual psyche, including perceptions and beliefs. It is the result of interaction with persons and environment (Baloğlu, 
2009). In this connection, the human behaviour is the set of actions that human beings perform and are conditioned by thought, ethics, experience and cultural values. Human beings, including family, society, social status, language and religion, are considered social creations and born in a socio-cultural environment. In this respect, a person develops numerous social interactions in social settings such as home, family and friends, other neighbourhood peers and relatives, and individual produces and affects his or her social interaction in all these social interactions and relationships.

The social behaviour is aimed at society and takes place within the same communities. When children grow up and mature, their social interaction continues to intensify through observing and copying other people's behaviours (Lopper, 2006). The interactions between individuals, typically within the same species, usually beneficial to one or more individuals are described as social behaviour. It is thought that social behaviour developed because it was advantageous to those who participated, implying that these people were more likely to survive and replicate. Social behaviour has a host of roles that can be seen in a wide range of people. Social behaviour changes over time, and facets of demography, such as birth and death schedules and lifespans, have been highly scrutinized as influences that may affect or be affected by the social processes (Badcock, 2015). Alden, Auyeung and Plasencia (2014) believe that approach, or the desire to achieve positive social outcomes, avoidance, or the desire to prevent adverse effects, are two partially separate motivational processes that motivate social behaviour, as they do all human behaviour.

\section{LITERATURE REVIEW}

A large number of studies divided social behaviour into two clear strands of the positive and negative social behaviour. Good attitudes are intended to promote the well-being and dignity of others. At the same time, negative behaviours are expected to restrict or harm another person's right, speech, integrity, or well-being(s). Negative behaviours are self-centered, with no regard for the happiness or needs of others. In contrast, positive behaviours have a desire to express not just the goals of others but also their suffering, anger, and sorrow. However, in this study, we are mainly focusing on negative social behaviour. Argyle (2013) concluded that NSB is a term that describes the behaviour of an individual who is not suitable and proper to society. Durlak, Weissberg, Dymnicki, Taylor and Schellinger (2011) mentioned and suggested that unequal opportunities and discrimination are significant factors to develop the NSB. Claypool, MClaypool, Smith, and Mackie (2014) argued that parents' income negatively affects children's ability to learn, so students have lost interest in learning and inclined towards destructive social behaviours.

Many other factors contribute to the growth of NSB of children, including family history and school-related factors. Family causes include weak parenting interactions with children that are closely linked to academic success, parents' economic status, poverty, parental unemployment, and parental history with the anti-social behaviour. Parents engaged in the use of drugs and alcohol disrupt family life. These influences lead to negative social experiences with the group, relatives, school climate and affect the child's disposition and ability (Korucu, Selcuk, \& Harma, 2017). Other causes, such as advertising abuse by television, movies, the internet and computer games, have vigorously escalated individual's infringement behaviour. Gender discrimination is a widespread factor among children. A large body of research has shown that the NSB can be enhanced or minimized by two main factors: push and pull factors. Zengyan, Yinping and Lim 
(2009) identify that push factors are negative factors that move individuals/students from one location to another. The pull factors are positive factors that attract/inspire people to stay or with stay.

Bogue and Hall (2003) suggested that push factors indicate the rejection of innate resources. Lack of jobs, problematic behaviour due to racial alliance, national, religious and less personal growth opportunities, natural disasters such as flooding, earthquakes, and pull considerations consist of greater work vacancies, higher income or schooling. Steffek (2013) said that the push variables provide the freedom to run away from a spot, and the pull variables mean that they are moved to the different location. Joynathsing and Ramkissoon (2010) expressed that push motives force the people to move towards another place. In this connection, they could include better school programs, cultural demands and environment needs for change, self-actualization and belonging. Push factors are those that, for various causes, lead individuals to transfer from one place to another, such as lack of the resources, poor parental economic conditions and its reasons are to lead students to leave college. Kainth (2009) also added that the push factors are those variables that, for some reasons, force a person to leave a position and drive to another venue.

Driving motives then create harmful conduct among students in which parents confront each other's or other family problems, hardship, bullying, intolerance, like divorce, parent quarrels. Joynathsing and Ramkissoon (2010) considered that pull factors are external influences that influence personal interest or preference. It suggests that pull variables include the attraction or interest of man to alter the atmosphere and climate, which are pull motivations such as the natural attractions of a man's interest. Kainth (2009) concluded that the pull factors mean encouraging a person to migrate to another area to raise wages, change working conditions and improve high housing standards for better living opportunities. The pull effect is a factor that motivates students to move from one location to another for better housing options and to change working conditions, like rural residents moving to urban areas because of high-paying jobs. The investigator claimed that push factors are better and strongly associated rather than pull factors. Push influences push people specifically to adopt negative attitudes. Retention aspects include the chance to update, relearn, develop new abilities and help them towards next level.

So, pull considerations mean external motivations or more desirable living environments with low violence, no teasing of others, no racist actions, and better living arrangements. The prime objective is to identify the push and pull factors of NSB among secondary school children. It was noticed during literature review that in Pakistan, this area has not previously been actively explored, and almost one study has been conducted to analyze this critical issue. In doing so, we plan to bring the problems to the light of high potential that push and pull factors of NSB have a worldwide effect. This article, accordingly, endeavours to bridge a portion of gaps in this area.

\section{Research Hypothesis}

The following research hypotheses were formulated in this study as developed from the main theme.

H1. There is significant effect of students' demographic variables on negative social behaviour. H2. There is significant effect of teachers' demographic variables on negative social behaviour. 


\section{RESEARCH METHODOLOGY}

The required methods for conducting reserrch have been offered in this cestion. The issue under investigation reflects on the actual situation and considers the scope of the sample, and it was felt that descriptive research design was suitable (Haider \& Hussain, 2014). The survey design was considered appropriate for extracting accurate results from various descriptive research designs and primary source of data collection for survey is interviews and questionnaires (Smith, 2001).

\section{Sampling Frame}

The study population consisted of all government secondary school students and teachers of the rural and urban areas in four selected districts of Bahawalpur, Multan, Sahiwal and Rawalpindi. The study sample of 500 students (252 female and 248 male) and 120 teachers (60 male and 60 female) were selected conveniently. Sample of 250 students was taken from rural school and 250 from urban secondary schools, whilst 60 teachers from rural and 6o from urban school. The students' mean age was 14.17 years $(\mathrm{SD}=1.22)$, and teachers' mean age was 37.17 years $(\mathrm{SD}=$ 8.98).

\section{Research Instrument}

The literature review and lengthy ongoing discussions with educational experts resulted from development and revision of the research instrument. For data collection, two questionnaires were developed, one for students and other for teachers. One page of demographic features was used in each questionnaire to get personal information related to demographic features (gender, age, location, family structure and qualification). The questionnaire for students comprised 25 close-ended questions, while teachers' questionnaire consisted of 28 closed-ended questions. In questionnaire, the questions related to self-control, teachers' feelings, aggression, care and pessimism were included. In students' questionnaire, 25 items were designed to measure three factors. The first factor, self-control (Items, 07), second factor, teachers' feelings (Items, 06) third factor, family/ parents' practices (Items, 08). In questionnaire for teachers, 28 items were developed to measure three dimensions. First dimension, aggression and quarrels (o6 items), second dimension, anger and actions (o9 items), while third dimension, betterment and positivity (o8 items).

\section{Reliability \& Validity of Scale}

A panel of experts established the object and face validity of research instruments. The contents of questionnaires receiving approval from the experts by $75 \%$ or more were retained, while the inappropriate questions were revised in the light of the criticism of experts. A small sample of 20 students and 10 teachers subsequently piloted the research instrument. Cronbach's alpha coefficient was calculated to assess the reliabilities of both the questionnaires. For the research instrument of students, the Cronbach's alpha values were: .86 for self-control, .79 for teachers' feelings factor, and .91 for family and parents' practices, whilst for teachers' questionnaire, the values were: .92 for aggression and quarrels, .83 for anger and actions and .85 for betterment and positivity.

\section{Data Collection \& Analysis}

The researchers personally collected required data from students and teachers of four selected districts. In this connection, the collected data was analyzed with SPSS 22nd version by using 
EFA with the principal component method (PCA) and varimax rotation, CFA, correlation and t-test.

\section{DATA ANALYSIS}

The process of data analysis takes place in two steps,. A factor analysis was initially conducted on two sets of questionnaires. similarly, the descriptive and inferential statistical measures were applied to data in second phase in order to find the answers of the research questions and reach conclusion.

\section{Table 1}

Factor Matrix for Students' Perspective of NSB

\begin{tabular}{|c|c|c|c|}
\hline \multirow[t]{3}{*}{ Items } & \multicolumn{3}{|c|}{ Component Factor Loading } \\
\hline & Self-Control & Teachers' & Family/Parents' \\
\hline & & Feelings & Practices \\
\hline 1. I feel guilty when I behave rudely. & .549 & & \\
\hline 4. I am concerned about the feelings of others. & .563 & & \\
\hline 5. I say sorry to person hurts by me. & .495 & & \\
\hline 6. When I do something wrong, I feel ashamed & .624 & & \\
\hline 7. I don't try to hurt others in order to win a match & .531 & & \\
\hline 13. I am punctual in studies. & .657 & & \\
\hline 14. I cooperate with friends. & .565 & & \\
\hline 8. I enjoy the bad feelings of others. & & .489 & \\
\hline 12. My teachers help me with my studies. & & .687 & \\
\hline 16. Teachers are responsible for promoting NSB & & .519 & \\
\hline 20. My teachers behave rudely with me. & & .682 & \\
\hline 22. I become rude when teachers scold me. & & .552 & \\
\hline 23. I feel comfort teasing my non-favourable teachers. & & .532 & \\
\hline 9. My financial problems make me angry. & & & .545 \\
\hline 10. My family problems disturb me. & & & .658 \\
\hline 11. Even in the worst conditions, my parents support me. & & & .599 \\
\hline 15. When I behave well, my parents appreciate me. & & & .608 \\
\hline 17. Negative behaviours come from learners & & & .500 \\
\hline 18. My parents' conflicts disturb me. & & & .479 \\
\hline 19. I feel lonely due to the attitudes of my parents. & & & .458 \\
\hline 21. I am encouraged by my parents about my plans. & & & .534 \\
\hline Total Variance Explained \% (57.14) & 14.47 & 19.23 & 23.44 \\
\hline
\end{tabular}

The exploratory factor analysis (EFA) was used to explore the factor structure in the research instruments (Table 1). A PCM followed by the Varimax rotation was conducted for both the questionnaires to extract the uncorrelated items. In students' data set, 21 items were finally retained after the analysis to measure three factors. Seven items $(1,4,5,6,7,13,14)$, six items $(8,12,16,20,22,23)$ and eight items $(9,10,11,15,17,18,19,21)$ loaded respectively on self-control, teachers' feelings and family/ parents' practices. Further CFA modification indices identified that fitness could be improved by deleting items 02, 03, 24 and 25 because they are indicating significant high correlations among the error variances. For remaining items, CFA model fit the data very well (Chi-square fitness $=7.641, \mathrm{df}=24, \mathrm{p}=0.024 ; \mathrm{CFI}=0.90 ; \mathrm{NNFI}=$ 
o.83; RMSEA $=0.038 ;$ IFI $=0.84 ; \mathrm{RFI}=0.87$ and $\mathrm{NFI}=0.86)$ while overall reliability scale was .84 .

In teachers' data set, 23 items were finally retained after analysis to measure three facets. Three factors were aggression and quarrels, six items $(5,12,20,22,25,27)$, anger and actions nine items $(2,3,7,9,10,14,21,24,28)$ and betterment and positivity eight items $(1,4,6,15,16,17$, 23, 26). Further CFA indicated high correlations among error variances of item 08, 11, 13, 18, and 19. So, modification indices suggested exclusion of these items for better model fit. CFA results for remaining items were (Chi-square fit quality $=6.192, \mathrm{df}=27, \mathrm{p}=0.194 ; \mathrm{CFI}=0.93$; $\mathrm{NNFI}=0.87 ; \mathrm{RMSEA}=0.040 ; \mathrm{IFI}=0.88 ; \mathrm{RFI}=0.81 ; \mathrm{NFI}=0.83$ ), while all reliability scale was .80 .

\section{Table 2}

Factor Matrix for Teachers' Perspective of NSB

\begin{tabular}{|c|c|c|c|}
\hline \multirow[t]{2}{*}{ Items } & \multicolumn{3}{|c|}{ Component Factor Loading } \\
\hline & $\begin{array}{l}\text { Aggression } \\
\text { \& Quarrels }\end{array}$ & $\begin{array}{c}\text { Anger \& } \\
\text { Actions }\end{array}$ & $\begin{array}{l}\text { Betterment \& } \\
\text { Positivity }\end{array}$ \\
\hline 5. Teachers insult their students in class. & .510 & & \\
\hline 12. Teachers promote the NSBs among students. & .551 & & \\
\hline 20. Students become aggressive with teachers. & .562 & & \\
\hline 22. Students start fighting on small matters. & 615 & & \\
\hline 25. Your students are involved in drug. & .555 & & \\
\hline 27. When students are teased, they break things. & .799 & & \\
\hline 2. Students take revenge when someone quarrels with them. & & .508 & \\
\hline 3. Students support the negative behaviours of their friends. & & .408 & \\
\hline 7. Students hurt others feelings. & & .553 & \\
\hline 9. Student hurt others when they are angry. & & .652 & \\
\hline 10. Students create discipline problems in class. & & .671 & \\
\hline 14. Students enjoy making fun of others. & & .541 & \\
\hline 21. Harassment is an everyday activity among school students. & & .691 & \\
\hline 24. Your students are involved in smoking. & & .489 & \\
\hline 28. Students start fighting to get what they want. & & .437 & \\
\hline 1. Students are concerned about the feelings of others. & & & .535 \\
\hline 4. Teachers ignore the rude behaviours of students. & & & .517 \\
\hline 6. Students realize their mistakes. & & & .579 \\
\hline 15. Students exclude others if they do something wrong. & & & .569 \\
\hline 16. You appreciate your students if they behave well. & & & .617 \\
\hline 17. You guide your students about their plans. & & & .460 \\
\hline 23. Misbehaving students are treated by school authority. & & & .714 \\
\hline 26. Students dislike the corrupt people of society. & & & .811 \\
\hline Total Variance Explained \% (64.05) & 12.11 & 24.74 & 27.20 \\
\hline
\end{tabular}

Both questionnaires have more than $83 \%$ content validity, whilst the convergent validity of the students' questionnaire was $89 \%$, and teachers' questionnaire was $83 \%$. Discriminant validity for students' questionnaire calculated $51 \%$. Thus, as the correlation was significant for teachers' questionnaire, so, it was impossible to figure the discriminant validity for the desired research instruments. 
Table 3

Correlation Matrix among NSB Dimensions

\begin{tabular}{lccccc}
\hline & 1 & 2 & 3 & 4 & 5 \\
\hline Students' & & & & & \\
1. Self-Control & - & & & & \\
2. Teachers' Feelings & - & - & & & \\
3. Family/ Parents' Practices & - & - & - & & \\
Teachers' & & & & & \\
4. Aggression and Quarrels & $-.221^{*}$ & .091 & -.051 & - & - \\
5. Anger and Actions & -.018 & -.002 & $-.224^{*}$ & $.325^{* *}$ & $-.242^{* *}$ \\
6. Betterment and Positivity & -.110 & .068 & $.786^{* *}$ & $-.560^{* *}$ & \\
\hline$* * \mathrm{p}<0.01,{ }^{*} \mathrm{p}<0.05$ & & & & & \\
\hline
\end{tabular}

The spearman's rho correlation between push and pull factors of NSB among secondary school students are manifested in (Table 3). A statistically low and moderate correlation was observed between study variables. Students' self-control has weak negative association with aggression and quarrels $(\mathrm{r}=-.221, \mathrm{p}<.05)$. Similarly, Family/parents practices has weak negative correlation with anger and action $(\mathrm{r}=-.224, \mathrm{p}<.05)$. Aggression and quarrels have weak positive correlation with anger and action $(\mathrm{r}=.325, \mathrm{p}<.01)$. Betterment and positivity have high positive correlation with family and parent practices $(\mathrm{r}=.786, \mathrm{p}<.01)$, moderate negative association with aggression and quarrels $(\mathrm{r}=-.560, \mathrm{p}<.01)$ and weak negative correlation with anger and actions $(\mathrm{r}=-.242$, $\mathrm{p}<.01)$.

\section{Table 4}

Students' Gender-wise Comparison of Self-Control, Teachers' Feelings \& Family Practices

\begin{tabular}{|c|c|c|c|c|c|c|c|}
\hline No & & Gender & $\mathrm{N}$ & Mean & SD & $\mathrm{t}$ & Sig \\
\hline \multirow[t]{2}{*}{1} & Self-Control & Boys & 248 & 3.26 & .60 & -.190 & .851 \\
\hline & & Girls & 252 & 3.27 & .52 & & \\
\hline \multirow[t]{2}{*}{2} & Teachers' Feelings & Boys & 248 & 2.26 & .59 & -.974 & .330 \\
\hline & & Girls & 252 & 2.31 & .56 & & \\
\hline \multirow[t]{2}{*}{3} & Family / Parents' Practices & Boys & 248 & 2.70 & .48 & 2.305 & .022 \\
\hline & & Girls & 252 & 2.79 & .44 & & \\
\hline \multirow[t]{2}{*}{4} & Negative Social Behaviour & Boys & 248 & 2.74 & .34 & 1.843 & .043 \\
\hline & & Girls & 252 & 2.79 & .29 & & \\
\hline
\end{tabular}

The students' gender-wise comparison regarding three facets of NSB was presented in Table 4. The mean value for self-control and teachers' feelings are not significantly different in boys' and girls' students. But, in family practices, mean difference is significant between both genders' boys $(\mathrm{M}=2.70, \mathrm{SD}=.48)$ and girls $(\mathrm{M}=2.79, \mathrm{SD}=.44)$. Significant sig value revealed that both genders differentiate significantly regarding family practices $\mathrm{t}(498)=2.305, \mathrm{Sig}=.022$. About NSB, both genders again have significant difference. High mean value of female shows that they have more aggressive behaviour as compared to boys $(\mathrm{M}=2.7 \mathrm{O}, \mathrm{SD}=.34)$ and girls $(\mathrm{M}=2.79$, $\mathrm{SD}=.29)$. Display more NSB in their daily dealing then male counterparts $\mathrm{t}(498)=1.843$, $\mathrm{Sig}=$ .043 . 
Table 5

Teachers' Gender-wise Comparison of Aggression \& Quarrels, Anger \& Actions, and Betterment \& Positivity

\begin{tabular}{llllllll}
\hline No & & Gender & N & Mean & SD & t & Sig \\
\hline 1 & Aggression \& Quarrels & Male & 60 & 2.18 & .60 & 1.882 & .033 \\
& & Female & 60 & 1.98 & .56 & & \\
2 & \multirow{2}{*}{ Anger \& Actions } & Male & 60 & 2.46 & .41 & .637 & .525 \\
\multirow{2}{*}{3} & \multirow{2}{*}{ Betterment \& Positivity } & Female & 60 & 2.41 & .45 & & \\
& & Male & 60 & 2.35 & .38 & 2.583 & .011 \\
& Negative Social Behaviour & Female & 60 & 2.51 & .31 & & \\
\hline & & Male & 60 & 2.38 & .38 & 2.106 & .037 \\
\hline
\end{tabular}

Table 5 revealed teachers' gender-wise comparison regarding three facets of NSB. Only mean value for anger \& actions are not significantly different in male and female teachers. Equally, the mean value for rest of other three factors was significantly different between both genders. Regarding aggression \& quarrels, both genders differ significantly, male $(\mathrm{M}=2.18, \mathrm{SD}=.60)$ and female $(\mathrm{M}=1.98, \mathrm{SD}=.56)$. As the higher mean value of male teachers manifest that they are more aggressive in their dealing with their students, and they usually display more violent attitude than female teachers $\mathrm{t}(118)=1.882, \mathrm{Sig}=.033$. Regarding betterment \& positivity, both genders again have a significant difference. Again, females have high mean value $(\mathrm{M}=2.51, \mathrm{SD}$ $=.31)$ as compared to male $(\mathrm{M}=2.38, \mathrm{SD}=.38)$. This revealed that female teachers are more polite, friendly, and cooperative with students and always try to make things better and have a positive attitude towards their students than male counterparts $\mathrm{t}(118)=2.583, \mathrm{Sig}=.011$. Also, regarding NSB, female teachers again have smaller mean value $(\mathrm{M}=2.25, \mathrm{SD}=.33)$ then male teacher $(\mathrm{M}=2.38, \mathrm{SD}=.38)$, which identified that male teachers are aggressive and display negative behaviour towards their students as compared to female teachers $\mathrm{t}(118)=2.106$, $\mathrm{Sig}=$ .037 .

\section{Table 6}

Effect of Students' Demographics on their Negative Social Behaviour

\begin{tabular}{lcccc}
\hline Demographic Variables & Model 1 & Model 2 & Model 3 & Model 4 \\
\hline & Self-Control & Teachers' Feelings & Family Practices & Students' NSB \\
Gender & .020 & .065 & .092 & .046 \\
Residential Area & .039 & -.057 & .003 & -.005 \\
Family System & $.128^{* *}$ & -.050 & -.022 & .018 \\
Father's Occupation & $.119^{* * *}$ & -.064 & $.106^{* *}$ & .116 \\
Father's Income & .030 & -.007 & .016 & $-.113^{*}$ \\
$\mathrm{~F}$ & $8.453^{* * *}$ & 2.289 & $1.373^{*}$ & $1.435^{* *}$ \\
$\mathrm{R}^{2}$ & .179 & .123 & .114 & .104 \\
\hline${ }^{*} \mathrm{p}<.05,{ }^{* *} \mathrm{p}<.01,{ }^{* * *} \mathrm{p}<.001$ & & & \\
\hline
\end{tabular}

Multiple regression analysis was performed to examine the effect of students' demographics on their NSB (Table 6). In the model first self-control, $17.9 \%$ variance is explained by students' demographics $\left(\mathrm{R}^{2}=.179, \mathrm{~F}(5,494)=8.453, \mathrm{p}<.000\right)$. In this first model, two factors, family 
system and father occupation, were evolved as main contributor. So, one unit increase in family system will result $12.8 \%(\beta=.128, p<.004)$ increase and one unit increase in fathers' occupation will cause $11.9 \%(\beta=.119, \mathrm{p}<.000)$ increase in students' self-control. Similarly, in model third family practices, $11.4 \%$ variance is explained by students' demographics $\left(\mathrm{R}^{2}=.114, \mathrm{~F}(5,494)=\right.$ $1.373, \mathrm{p}<.045)$. Though, in this model, only a single factor, father's occupation, emerged as the main predictor. Hence, one unit increase in father's occupation will cause $10.6 \%(\beta=.106, p<$ .008 ) increase in students' family practices. In the final model, effect of students' demographics on students' NSB was measured. Total $10.4 \%$ variance is explained by independent variables $\left(\mathrm{R}^{2}=.104, \mathrm{~F}(5,494)=1.435, \mathrm{p}<.002\right)$ on dependent variable. In this model, only the effect of father's income was found significant. However, this effect was negatively associated. So, one unit increase in father's income will cause $11.3 \%(\beta=-.113, \mathrm{p}<.039)$ decrease students' NSB. So, it can be argued that as father's income increases, chances of students displaying negative attitude or involve in negative activities increases if the parents ignored the proper check and balance.

Table 7

Effect of Teachers' Demographics on their Negative Social Behaviour

\begin{tabular}{lcccc}
\hline Demographic Variables & Model 1 & Model 2 & Model 3 & Model 4 \\
\cline { 2 - 5 } & $\begin{array}{c}\text { Aggression \& } \\
\text { Quarrels }\end{array}$ & $\begin{array}{c}\text { Anger \& } \\
\text { Actions }\end{array}$ & $\begin{array}{c}\text { Betterment \& } \\
\text { Positivity }\end{array}$ & Teacher' NSB \\
Gender & -.240 & -.047 & -.008 & -.162 \\
Residential Area & -.008 & .041 & -.094 & -.021 \\
Academic Qualification & -.006 & -.072 & $.198^{* *}$ & -.028 \\
Professional Qualification & .075 & .011 & $.066^{*}$ & .051 \\
$\mathrm{~F}$ & 1.409 & 0.471 & $3.411^{* *}$ & 1.746 \\
$\mathrm{R}^{2}$ & .047 & .016 & .106 & .057 \\
\hline${ }^{*} \mathrm{p}<.05,{ }^{* *} \mathrm{p}<.01$ & & & &
\end{tabular}

Results of multiple regression analysis in table 7 identified only effect of teachers' demographics in model 3. In this model betterment \& positivity, $10.6 \%$ variance is explained by independent variable $\left(\mathrm{R}^{2}=.106, \mathrm{~F}(4,115)=3.411, \mathrm{p}<.004\right)$. In this connection, two factors, academic and professional qualification, have emerged as main predictors. Consequently, one unit increase in academic qualification will cause 19.8\% $(\beta=.198, \mathrm{p}<.001)$ increase and one unit increase in professional qualification will result $6.6 \%(\beta=.066, \mathrm{p}<.036)$ increase in teachers' betterment and positivity. However, effect of other variables was insignificant in the multiple regression process.

\section{DISCUSSION}

Perhaps the most significant of the many observational findings mentioned above is prevalence and clarification of different push and pull factors among the NSB of secondary school students in Punjab. It is the first comprehensive study in Punjab to examine factors that influence NSB among secondary school students. The analysis indicates that several variables affect negative attitudes of learners. These causes include tensions of parents, misbehaving family structure, social pressure, intimidation, insulting actions of teachers and psychological and personal issues of pupil. These variables are heading towards anti-social habits such as teasing, threatening, bullying, sexual violence, physical risk, smoking, alcohol and substance usage. And the findings 
suggest that latter has risen disproportionately over the last decade. In this connection, in this research, various important factors related to the schooling, such as disrespectful actions of the teachers, the mocking and insulting behaviours in the concerned schools, outdated syllabuses, conventional educational techniques, and lack of the moral education of students, often play a detrimental role in the character development of the students and these variables de-motivate students.

In these cases, students disregard the laws of schools and mistreat themselves. Based on results obtained from the comparison of mean score among boys' and girls' students, it is evident that girls have a more aggressive attitude at the secondary level than boys' students. This aggression sometimes causes teachers' disrespect, bullying fellow students and showing violent behaviour at home. This aggressiveness may be due to several physical and emotional changes that a girl undergoes at this age level. Boys experience the same material and dynamic changes and face emotional imbalance. But, these changes are not very frequent in boys at this stage as compared to girls. Gordon, Wilma, and John (2000) have proposed methods for discipline that instructor could apply in classroom. Clarify and define the laws and regulations of school and classroom that students must obey. Moreover, the results obtained from comparison of mean score among male and female teachers revealed that male teachers are more aggressive in their actions and dealing with students than female teachers and usually display violent attitudes. Lehr, Johnson, Bremer, Cosio, and Thompson (2004) expressed that learner who contributes to innovative environments are psychologically active in certain kinds of participation, including academic involvement, daily attendance, interpersonal engagement in classroom activities and extracurricular activities.

Furthermore, results also revealed that female teachers have a high mean score in behavioural positivity and educational betterment. Their high mean scores identified that female teachers are more polite, friendly, and cooperative with students and always try to make things better and positively affect their students than male teachers. This involvement develops consistency of partnership of student instructor. Edgar and Rhonda (2000) provides several recommendation to address negative attitudes and build a supportive atmosphere to improve friendship between instructor and students by giving guidance on personal problems. Peer tutoring organizes the class dialogue session they participate in and leads to conclusion of the learning object. Ananga (2011) proposes that school management committee should set up influential parent-teacher association to resolve these concerns. They work together to push children to stay in school. Parents should also encourage and involve children in education because pupils recover when parents show concern. When they ensure their children go to school, their progress improves very well. Bassey and Iruoje (2016) suggest that school should develop positive relationships over classroom activities and participation in extracurricular activities to become the lifetime learner.

Further recommended that improving teachers' quality helps to make sure that students achieve their possibility. According to him, no education can appear through quality of teachers. Gross and Pelcovitz (2012) said that classroom teacher represents like a primary mediator for moving out the social functions of the schools. He reported that some behaviours of the students in the classroom that their teachers observed include nervousness, loneliness, breaking the rules, and rowdiness for the last decades. He also suggested that religious education should be focused more than academics, through which ethical and moral values develop in behaviour. Aliakbari 
and Bozorgmanesh (2015) suggested that teachers always try to keep their classrooms free from disturbance. Manage the class and control the learners' behaviour in affectionate the ways like encouragement, motivation, and develop positive behaviour. Likewise, further viewed that the intellectual, physical, social abilities, and competencies should develop among learners for the development of society. To establish an education schedule and policy, parents should play an active role and stay involved with the learning. The parents' responsibility to provide a healthy environment gives love and care because these factors develop the behavioural problems among students.

\section{CONCLUSION}

Based on study results, it can be concluded that teachers, as cornerstone of teaching-learning process, should know their role and duties. They should consider academic needs of students and have proper instruction for them. The results provide significant information in reaching the concludion. Here, the pre-service and in-service teacher training are vital, emphasizing the duties of teachers. School can play a positive role in eradicating the negative behaviours among students and teachers. The school should arrange games and co-curricular activities in which students participate and build up social relations. In this connection, media must produce and transmit programs incorporating moral lessons underpinning our social values to promote positive social behaviour among the audiences, particularly students in particular situations. In this regrd, the parents and teachers should try to appreciate their children when they behave well in the desired manners. This strategy will serve as a positive reinforcement to the young ones.

\section{REFERENCES}

Alden, L. E., Auyeung, K. W., \& Plasencia, L. (2014). Social anxiety and the Self-Social Anxiety (pp. 531-549): Elsevier.

Aliakbari, M., \& Bozorgmanesh, B. (2015). Assertive classroom management strategies and students' performance: The case of EFL classroom. Cogent Education, 2(1), 1-12. doi: https://doi.org/10.1080/2331186X.2015.1012899.

Ananga, E. (2011). Dropping Out of School in Southern Ghana: The Push-Out and Pull-Out Factors. CREATE Pathways to Access. Research Monograph, No. 55: ERIC.

Argyle, M. M. (2013). The Scientific Study of Social Behaviour (Psychology Revivals): the Routledge.

Badcock, C. R. (2015). Nature-nurture controversy, history of. Wright, \& D. James International encyclopedia of the social \& behavioural sciences, 340-344.

Baloğlu, N. (2009). Negative Behaviour of Teachers with Regard to High School Students in Classroom Settings. Journal of Instructional Psychology, 36(1). 69-78

Bassey, B., \& Iruoje, J. (2016). Test anxiety, attitude to schooling, parental influence, and peer pressure as predictors of students cheating tendencies in examination in Edo state, Nigeria. Global Journal of Social Sciences, 15(1), 39-46.

Bogue, E. G., \& Hall, K. B. (2003). Quality and accountability in higher education: Improving policy, enhancing performance: Greenwood Publishing Group.

Claypool, H., MClaypool, H. M., Smith, E. R., \& Mackie, D. M. (2014). Social Psychology: Fourth Edition (4th ed.): New York: Psychology Press. https://doi.org/10.4324/ 9780203833698.

Cochran-Smith, M. (2001). Constructing outcomes in teacher education. Education policy analysis archives, 9, 11. 
Durlak, J. A., Weissberg, R. P., Dymnicki, A. B., Taylor, R. D., \& Schellinger, K. B. (2011). The impact of enhancing students' social and emotional learning: A meta-analysis of schoolbased universal interventions. Child development, 82(1), 405-432.

Edgar F, B., \& Rhonda J. V. M. (2000). The Encyclopedia of sociology: Macmillan Reference USA.

Gazi, A. K. (2020). Push and Pull Factors for Dropping Out of High School in Bangladesh. Paper presented at the International Conference on Management, Engineering, Science \& Social Science, organized by International Institute of Academic Research \& Publications (IIARP), Global Empowerment Trust., Online / Virtual Conference.

Gordon, W., Wilma, G., \& John, A. (2000). Regional training seminar on guidance and counselling. France: Unesco.

Gross, K. G., \& Pelcovitz, D. (2012). Teachers' Perceptions of Distress and Disturbance Regarding Students' Behaviour in an Elementary School Classroom. Journal of Elementary in Education, 22(2), 57-59.

Haider, S. Z., \& Hussain, A. (2014). Relationship between teacher factors and student achievement: A correlational study of secondary schools. US-China Education Review A, 4(7), 465-480.

Joynathsing, C., \& Ramkissoon, H. (2010). Understanding the behavioural intention of European tourists. Paper presented at the International Research Symposium in Service Management ISSN.

Kainth, G. S. (2009). Push and pull factors of migration: a case of brick kiln industry of Punjab State. Asia-Pacific Journal of Social Sciences, 1(1), 82-116.

Korucu, I., Selcuk, B., \& Harma, M. (2017). Self-regulation: Relations with theory of mind and social behaviour. Infant and Child Development, 26(3), 1-23. Doi: https://doi.org/ 10.1002/icd.1988.

Lehr, C., Johnson, D., Bremer, C. D., Cosio, A., \& Thompson, M. (2004). Essential tools: Increasing rates of school completion: Moving from policy and research to practice. Minneapolis, MN: National Center on Secondary Education and Transition, 1-84.

Lopper, J. (2006). What is attitude? Inclination toward positive or negative ways of thinking. Suite101. com.

Steffek, J. (2013). Explaining cooperation between IGOs and NGOs-push factors, pull factors, and the policy cycle. Review of international studies, 39(4), 993-1013.

Valiente, C., Eisenberg, N., Haugen, R., Spinrad, T. L., Hofer, C., Liew, J., \& Kupfer, A. (2011). Children's effortful control and academic achievement: Mediation through social functioning. Early Education \& Development, 22(3), 411-433.

Zengyan, C., Yinping, Y., \& Lim, J. (2009). Cyber migration: An empirical investigation on factors that affect users' switch intentions in social networking sites. Paper presented at the 2009 42nd Hawaii International Conference on System Sciences. 